\title{
Skin Improvement Effect of Tencel Sheet Mask Pack Using Self- luminous LED Light Source
}

Hye Jeong Koo, Ki Han Kwon

Division of Beauty Arts Care, Department of Practical Arts, Graduate School of Culture and Arts, Dongguk University, Seoul, Korea

\author{
*Corresponding author: Ki Han Kwon, \\ Division of Beauty Arts Care, Department of \\ Practical Arts, Graduate School of Culture \\ and Arts, Dongguk University, 30, Pildong- \\ ro 1-gil, Jung-gu, Seoul 04620, Korea \\ Tel.: +82 222901659 \\ Fax: +82 222603741 \\ Email: kihan.kwon@dongguk.edu
}

Received September 07, 2021

Revised October 25, 2021

Accepted October 27, 2021

Published December 30, 2021

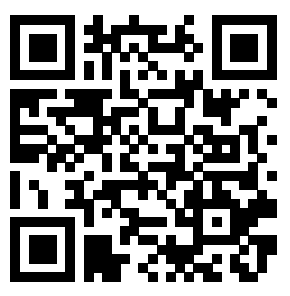

\begin{abstract}
Purpose: This study intends to prove whether the efficacy already proven in the existing light therapy LED mask device is similarly exerted in the self-luminous LED sheet mask that does not require power. Methods: The experimental subjects of this study were women with an average age of 47.9 years, and the effect of improving 24-hour moisturizing lasting, skin elasticity, eye expression wrinkles, and facial (cheek) lifting was studied by prohibiting the use of cosmetics containing active ingredients that could affect the results and making them use an LED sheet type mask pack. Results: As a result of the experiment, the 24-hour moisturizing lasting power was $90.573 \%$ immediately after use and $37.384 \%$ after 24 hours, so it increased significantly $(p<0.05)$, and skin elasticity was also increased by $7.087 \%$ immediately after use. After one week, it was increased significantly $(p<0.025)$ to $11.181 \%$. Expression wrinkles around the eyes were significantly reduced $(p<0.05)$ to $1.621 \%$ immediately after use and $4.579 \%$ after 1 week of use. In the facial (cheek) lifting experiment, the cheek angle $\left({ }^{\circ}\right)$ was reduced to $2.065 \%$ immediately postuse compared to pre-use. Also, it was significantly decreased $(p<0.05)$ with a result of $3.762 \%$ after 1 week of use, thus proving that the light therapy LED sheet mask is also effective for skin improvement. Conclusion: Using this research material as basic data, it is expected that various skincare products will be developed as well as mask packs with a simple and easy structure of effective light therapy.
\end{abstract}

Keywords: Self-luminous LED, Light therapy, LED sheet mask pack, Skin moisturizing, Skin elasticity

\section{Introduction}

Light Therapy using sunlight is a medical technique that has been practiced since ancient times for treating skin diseases (Roelandts, 2005) treatments using LED light sources for the scalp, acne, and skin diseases have already been proven (Gupta et al., 2013). Currently, dermatological treatment and hair loss treatment (Avci et al., 2014; Kim et al., 2010) devices using various LED lights have been developed. The LED Mask Device uses electric power and outputs three light sources: Red (630 $\mathrm{nm})$, green $(520 \mathrm{~nm})$, and Near-infrared ray $(660-950 \mathrm{~nm})$ to show a therapeutic effect. It is a skincare device that can transmit the most beneficial wavelength band to the skin (Ko, 2021,
Kim et al., 2020). Each wavelength band has a different effect on the skin cell layer. The blue light source has the lowest skin transmittance and is an effective light source for sterilization, prevention of wound infection, and oily skincare by taking care of the stratum corneum. The red-light source reaches the dermis layer and is effective in collagen production, regeneration, and elasticity of the skin, so it is a light source widely used for acne treatment. The yellow light source is effective in lifting, collagen synthesis, whitening, and fine wrinkles (Lee et al., 2020; Shen et al., 2018). With the advent of the COVID-19 virus in 2020, it has become difficult to visit specialized institutions such as dermatologists or dermatology hospitals. Therefore, small home care LED mask device with a simple structure developed for 
skin beauty and home care has been recently commercialized. LED device masks that can manage facial skin alone using the aforementioned three wavelengths are increasingly being commercialized. Furthermore, a self-luminous LED sheet mask sheet that does not require electric power and does not pose a risk to the human body has been developed by supplementing the shortcomings of skincare using electric power. The efficacy of the sheet mask will be verified in this article (Wheeland \& Dhawan, 2011). Although the LED Mask Device must be used regularly for effective skincare, it has its own disadvantages such as expensive, hygienic parts such as washing, the hassle of power supply and waiting for charging, and the risk of exposure to electromagnetic waves. Users will have to take care of their skin while dealing with these shortcomings. On the other hand, the sheet-type mask pack is the most convenient and affordable home care cosmetic product with high satisfaction. Therefore, if the convenience and efficacy of the LED sheet mask are proven (Kim \& Jeon, 2020), more general skincare can be expected for home care in COVID-19 Pandemic. Recently, a patent has been developed for a Light Therapy LED sheet type mask pack that combines the satisfaction and convenience of skincare with the efficacy of Light Therapy. This product converts the surrounding light into the wavelength of the Light Therapy effect and outputs it without using power for the sheet-type mask pack. In other words, it is a mask sheet that has the same effect as the LED mask device for Light Therapy. In previous papers on the LED Mask Device, skin improvement effects were proven when using a LED lamp (Ko, 2021), but the skin improvement effect of the recently developed LED sheet mask that does not require electric power has not been proven yet. Therefore, this experiment was conducted in anticipation of the skin improvement effect for the rapid spread of new and creative inventions and the development of $\mathrm{K}$-beauty.

In this study, it was proved that it is possible to effectively improve and manage skin with a relatively low-cost sheet-type mask pack that has the effect of Light Therapy while solving the inconvenience of the conventional LED mask device.

\section{Methods}

\section{Experimental materials and research subjects}

In this study, 23 women aged 35 to 55 with eye wrinkles were selected as test subjects through Company M (Seoul, Korea), and comparison experiments were conducted before and after they used the Light Therapy sheet mask face pack product. The product name of this light therapy sheet mask face pack is Ariul L.E.D. lumi mask. This mask was conducted with the support of 2021 Beauty Factory Co., Ltd., Seoul, Korea.

In the experiments, after they wash their face, the test subjects attach the printed side of the Light Therapy mask sheet to the skin on their dry face.

After about 15 minutes, remove the sheet and tap the contents to absorb it.

In order to verify the efficacy of the Light Therapy LED sheet mask pack, the effects of 24-hour moisturizing durability evaluation, skin elasticity evaluation, eye expression wrinkles evaluation, and facial (cheek) lifting were tested on women with an average age of 47.9 years for one week. It was intended to prove the skin improvement effect of the Light Therapy LED sheet type mask pack.

\section{Assessed area and evaluation methods}

The test was conducted once a day for 7 days, and a survey was conducted after skin evaluation through 3 visits. At the first visit, after explaining the trial and signing the consent form to participate in it, a demographic survey, selection/ exclusion criteria review, and medical history were conducted. Finally, they were told how to use the test product. Before and immediately after using the test product, 24 hours of moisturizing durability, skin elasticity, eye expression wrinkles, and facial (cheek) lifting were evaluated, and skin symptoms were evaluated. In the second visit, adverse reactions that occurred later after using the product and whether or not combination treatment was performed were investigated, and 24-hour moisturizing durability evaluation and skin symptom evaluation were performed. At the 3rd visit, adverse reactions occurring after the 2 nd visit and the combination treatment were investigated, and skin elasticity, eye expression wrinkles, facial (cheek) lifting evaluation, and skin symptoms were evaluated one week after using the test product. After the end of the test, an efficacy evaluation survey and a product preference survey were conducted.

Considering the evaluation of the equipment, the test subject took a rest for 30 minutes in a waiting room with a constant temperature and humidity at an indoor temperature of $20-25^{\circ} \mathrm{C}$ and humidity of 40-60\%. The surface temperature and humidity of the skin were applied to the environment of the evaluation 
space, and water intake was restricted while they were at rest. For objective evaluation, one researcher has analyzed the same area for every test.

\section{24-hour moisture retention evaluation}

The 24-hour moisturizing durability evaluation was analyzed using a Corneometer CM825 (Courage-Khazaka electronic $\mathrm{GmbH}$, Germany). The same left forearm area was evaluated before and after using the test product. During the evaluation, the Corneometer probe was applied to the skin and the sensor was applied three times, and the average value was used as the water content evaluation data. Corneometer basically recognizes the skin as a non-conductor and evaluates the capacitance where the probe is in contact, as it is a device that applies the property of conducting electricity better as it contains more moisture. Therefore, moisture content and capacitance are proportional to each other, and it can be seen that the higher the evaluation value, the higher the moisture content. A unit is an arbitrary unit (A.U.), which is a number of water units.

\section{Skin elasticity evaluation}

For skin elasticity evaluation, the R2 (skin re-strain force) value was measured on the same right cheek area of the test subject before and after using the test product using Cutometer ${ }^{\circledR}$ MPA 580 (Courage-Khazaka electronic GmbH, Germany) and used as skin elasticity evaluation data. The R2 value means that the closer the overall elasticity is to 1 , the more elastic the skin is.

\section{Eye expression wrinkles evaluation}

For eye expression wrinkles evaluation, the same left eye area of the test subject was photographed before and after using the test product using Antera 3D CS (Miravex Ltd., Ireland), a 3D skin imaging device. The image was saved and converted to Wrinkles (Medium) mode, the analysis range was specified, and the indentation index (A.U.) value within the range was analyzed. As the A.U. value decreases, it can be seen it is effective in improving eye expression wrinkles.

\section{Facial (cheek) lifting improvement}

For facial (cheek) lifting evaluation, Fray (BEYOUNG Co., Ltd, Korea), a device that expresses the appearance of the skin as a contour line, was used. The same left face of the test subject was photographed before and after the use of the test product,

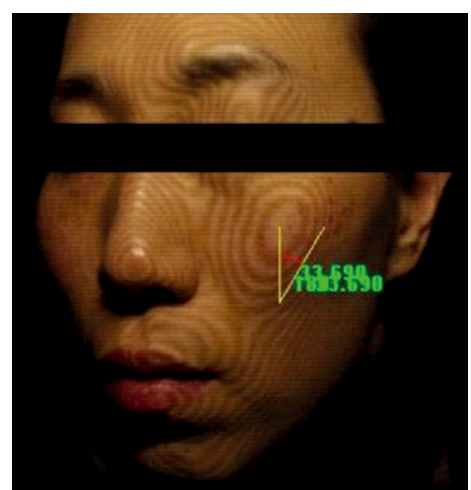

Figure 1. Facial (cheek) lifting example image.

and analysis was performed based on the curve created near the area. The captured images ( $30^{\circ}$ side view) were analyzed using Image-pro® plus (Media Cybernetics, USA). For facial (cheek) lifting, draw a straight line downward from the center of the circle formed near the cheekbones and move 3 spaces to the right along the horizontal stripe drawn in the contour picture from the starting point where it meets the contour line below. From there, a straight line was drawn as the inner boundary point in contact with the pattern opposite to the starting circle, and the angle $\left(^{\circ}\right)$ between the two straight lines was measured and evaluated. It means that as the angle $\left(^{\circ}\right)$ between two straight lines decreases, it is effective in improving ball lifting (Figure 1).

\section{Efficacy survey}

After using the test product, they were asked to directly answer the questionnaire data in five stages of evaluation: very good (4), good (3), average (2), bad (1), and very bad (0). The researcher calculated the percentage of the number of subjects for each answer to determine the efficacy of the test product.

face of the test subject was photographed before and after the use of the test product, and analysis was performed based on the curve created near the area. The captured images $\left(30^{\circ}\right.$ side view) were analyzed using Image- pro $^{\circledR}$ plus (Media Cybernetics, USA). For facial (cheek) lifting, draw a straight line downward from the center of the circle formed near the cheekbones and move 3 spaces to the right along the horizontal stripe drawn in the contour picture from the starting point where it meets the contour line below. From there, a straight line was drawn as the inner boundary point in contact with the pattern opposite to the starting circle, and the angle $\left(^{\circ}\right)$ between the two straight 
lines was measured and evaluated. It means that as the angle $\left(^{\circ}\right)$ between two straight lines decreases, it is effective in improving ball lifting (Figure 1).

\section{Product preference survey evaluation}

Regarding the feeling of use after using the product, the test subject was asked to directly answer some questionnaires. The evaluation contents were divided into 5 levels of very good (4), good (3), normal (2), bad (1), and very bad (0) for skin moisture, skin smoothness, adhesion, absorbency, fragrance, and overall feeling of use.

\section{Stability evaluation}

For the safety of the test product, the incidence rate of adverse reactions was calculated by synthesizing the adverse reactions confirmed for all test subjects using the test product and all adverse reactions reported during the test period and used as safety evaluation data of the product.

\section{Adverse reaction evaluation}

For the safety of the test product, the incidence rate of adverse reactions was calculated by synthesizing the adverse reactions confirmed for all test subjects using the test product and all adverse reactions reported during the test period and used as safety evaluation data of the product.

\section{Evaluation criteria}

1) Usability evaluation variation 1

The primary efficacy evaluation variation of the test product was evaluated based on the evaluation values for 24-hour moisture retention, skin elasticity, eye expression wrinkles, and facial (cheek) lifting before and after using the test product.

\section{2) Usability evaluation variation 2}

The secondary efficacy evaluation variation of the test product was evaluated based on the results of an efficacy evaluation survey on the skin improvement effect after using the test product.

\section{Statistical analysis}

Before using the test product, SPSS 19.0, a statistical analysis program, was used to examine the significance of the comparison evaluation value. Significance was confirmed when the probability of significance was $p<0.05$ in the $95 \%$ confidence interval and the probability of significance was rounded up to the third decimal place. Continuous variables were summarized as mean and standard deviation, and categorical variables were summarized as frequency and percentage. For more than 3 repeated evaluation data, repeated-measures ANOVA was used as a parametric method after normality qualification, and postqualification was conducted by the Bonferroni method. The non-parametric method was compared with Wilcoxon signedrank test using the Friedman test, and the significance level was corrected by the Bonferroni method to measure postqualification. The comparison between groups was compared using the rate of change compared to before use, and the nonparametric Mann-Whitney U test was used after normality qualification.

Table 1. Age of test subjects

$(\mathbf{N}=\mathbf{2 3})$

\begin{tabular}{|c|c|c|c|}
\hline full age (years) & $\mathrm{N}$ & $\%$ & \\
\hline $20-29$ & 0 & 0.000 & \\
\hline $30-39$ & 4 & 17.391 & \\
\hline $40-49$ & 8 & 34.783 & \\
\hline $50-55$ & 11 & 47.826 & \\
\hline \multicolumn{3}{|c|}{ Table 2. Skin condition and age of test subjects } & $(\mathrm{N}=23)$ \\
\hline Skin condition & $N$ & $\%$ & \\
\hline Dry & 7 & 30.435 & \\
\hline Moderate dry & 9 & 39.130 & \\
\hline Neutral & 5 & 21.739 & \\
\hline Moderate oily & 1 & 4.348 & \\
\hline Oily & 1 & 4.348 & \\
\hline
\end{tabular}




\section{Result and Discussion}

\section{Statistical analysis}

The mean age of 23 test subjects who completed this study was 47.913 years old women; 4 in their 30s, 8 in their 40s, and 11 in their 50s (Table 1).

\section{Skin condition of test subject}

The skin conditions of 23 test subjects who completed this test were dry skin type 7 patients, moderate dry skin 9 patients, neutral skin 5 patients, moderate oily skin 1 patient, and oily skin 1 patient (Table 2).

\section{Skin characteristics of test subject}

For each test subject, there were no corresponding test subjects in the questionnaire about skin diseases, itchiness, stinging, erythema, cosmetic side effects, drug side effects, light sensitivity, atopic disease, or others (Table 3).

\section{Efficacy evaluation result 1}

1) 24-hour moisturizing lasting evaluation result
The LED light produces collagen and elastin in the skin and suppresses the occurrence of wrinkles to moisturize the skin and maintain elasticity (Kim \& Kang, 2021). Usually, there is a result that ultraviolet or light has a bad effect on skin aging (Lee \& Kim, 2007), but through this experiment, it was also proved that there is a positive effect on the production of hyaluronic acid and protein on the skin depending on the type of light and the intensity of exposure. Therefore, it was tested whether the LED sheet mask used in this experiment had the same effect (Shim, 2020). In order to check the moisture of the skin when using the LED mask sheet, a 24-hour moisturizing durability test was conducted to check how tightly it holds and maintains the moisture of the skin. This experiment is not data that can be compared with general functional mask packs on the market. However, it can be seen the LED sheet mask contributed to the efficacy of the moisturizing durability because significant results were derived only with the LED sheet mask that did not contain any ingredients.

In this test, the results of moisturizing durability before use, immediately after use, and 24 hours after use after the subject product was used by the subjects are shown in Table 4 . When

Table 3. Survey result of test subjects

\begin{tabular}{lll}
\hline Skin condition & N & $\%$ \\
Skin disease & 0 & 0.000 \\
Itchiness & 0 & 0.000 \\
Stinging & 0 & 0.000 \\
Erythema & 0 & 0.000 \\
Cosmetic side effects & 0 & 0.000 \\
Drug side effects & 0 & 0.000 \\
Light sensitivity & 0 & 0.000 \\
Atopic disease & 0 & 0.000 \\
\hline
\end{tabular}

Table 4. 24-hour moisturizing lasting evaluation results

(Unit: A.U.)

\begin{tabular}{|c|c|c|c|}
\hline Classification & Test product & Unapplied & Improvement rate (\%) \\
\hline Before use & $31.377 \pm 6.520$ & $31.265 \pm 6.543^{1)}$ & \\
\hline Immediately after use & $59.796 \pm 10.953$ & $32.359 \pm 6.674$ & $90.573 \%$ \\
\hline 24 hours after use & $43.107 \pm 8.915$ & $32.865 \pm 6.229$ & $37.384 \%$ \\
\hline \multirow{3}{*}{ Non-probability within comparison } & Qualification of effects within the subject & $0.000^{* *}$ & 0.094 \\
\hline & Before use-Immediately after use & $0.000^{* *}$ & / \\
\hline & Before use-24 hours after use & $0.000^{* *}$ & / \\
\hline \multirow{2}{*}{ Non-probability among comparison } & Before use-Immediately after use & $0.00^{\ddagger}$ & / \\
\hline & Before use-24 hours after use & $0.00^{\ddagger}$ & / \\
\hline
\end{tabular}

${ }^{* *} p<0.05$ by repeated measures ANOVA, post hoc Bonferroni correction. ${ }^{\ddagger} p<0.05$ by Mann-Whitney U test. Improvement rate $(\%)=(($ After-Before $) /$ Before $) \times 100$

${ }^{1)}$ Mean \pm standard deviation. 
the Light Therapy LED sheet mask pack was not applied, it was confirmed that there was no significant difference in the subject's moisture content, but a change in moisture content of $90.573 \%$ was evaluated immediately after use. In addition, to confirm the durability, the moisture content was maintained at $37.384 \%$ after 24 hours of application in the experiment. Compared to the area where the test product was not applied, a significant difference $(p<0.05)$ was observed immediately after use and 24 hours after use compared to before use, so it can be concluded that the Light Therapy LED sheet mask pack is effective in moisturizing durability (Table 4).

\section{2) Skin elasticity evaluation result}

Table 5 shows the skin elasticity evaluation results of before use, immediately after use, and 24 hours after use of the subjects who used the test product. According to Ronald G Wheelan's evaluation of self-treatment of mild-to-moderate facial acne with a blue light treatment system (Wheeland \& Dhawan, 2011), the wavelength band of red light is relatively longer than that of blue light and yellow light. Therefore, it has been reported that it penetrates the subcutaneous fat layer and significantly helps skin regeneration and elasticity including acne treatment.

It is difficult to think that it has the same wavelength band, but the elasticity evaluation of the test product showed that the elasticity increased by $7.087 \%$ compared to before and after the use of the Light Therapy LED sheet mask pack, and the result of one week after use was $11.181 \%$ elasticity improvement. Therefore, as a result of the change in skin elasticity of the test product after use, compared to before use, immediately after use, and one week after use $(p<0.025)$ significantly increased ( $p<0.025)$, showing an effect on skin elasticity, self-luminescence that helps elasticity It was proved that it is a sheet mask (Table 5)

\section{3) Eye expression wrinkles evaluation result}

The thin epidermal layer around the eyes is one of the causes of presbyopia because wrinkles start to appear around the age of 25 and increase rapidly after the age of 40 . Therefore, it is necessary to manage it frequently from the early 20 s, but the accessibility is not good due to the dangers, high cost, reduced go outs due to covid-19 and various disadvantages of LED (Choi et al., 2013). Light Therapy helps to improve the skin by treating it with light (Ng et al., 2020), but it can also cause burns to the thin or sensitive areas of the epidermis. In particular, there are

Table 5. Skin elasticity evaluation results

\begin{tabular}{llcc}
\hline Classification & & $\mathrm{R} 2$ & Improvement rate (\%) \\
Before use & & $0.635 \pm 0.039^{1)}$ & 7.087 \\
Immediately after use & & $0.680 \pm 0.036$ & $11.181 \%$ \\
One week after use & Effect within the entity qualification & $0.706 \pm 0.036$ & $0.000^{\# \#}$ \\
$\begin{array}{l}\text { Within significance comparison } \\
\text { probability }\end{array}$ & Before use-Immediately after use & $0.000^{\# \#}$ & $0.000^{\# \#}$ \\
& Before use-one week after use & & \\
\hline
\end{tabular}

$\# p<0.025(=5 \% / 2)$ by Friedman test, post hoc Wilcoxon signed-rank test with Bonferroni correction. Improvement rate $(\%)=(($ After-Before $) /$ Before $) \times 100$

${ }^{1)}$ Mean \pm standard deviation.

Table 6. Evaluation result of eye expression wrinkle, indentation index

\begin{tabular}{llcc}
\hline Classification & & Indentation index (A.U.) & Improvement rate (\%) \\
Before use & & $29.371 \pm 7.305^{1)}$ & $1.621 \%$ \\
$\begin{array}{l}\text { Immediately after use } \\
\text { One week after use }\end{array}$ & $28.895 \pm 7.294$ & $4.579 \%$ \\
$\begin{array}{l}\text { Within significance comparison } \\
\text { probability }\end{array}$ & Effect within the entity qualification & $28.026 \pm 7.316$ & $0.000^{\# \#}$ \\
& Before use-Immediately after use & $0.000^{\# \#}$ & $0.000^{\# \#}$ \\
\hline
\end{tabular}

${ }^{\# \#} p<0.05$ by repeated-measures ANOVA, post hoc Bonferroni correction.

Improvement rate $(\%)=(($ After-Before $) /$ Before $) \times 100$

${ }^{1)}$ Mean \pm standard deviation. 
research results that suggest the possibility to harm the eyes (photokeratitis, cataract, conjunctivitis, etc.) due to the strong light rays. However, according to the results of other studies, it was announced that there was no abnormality in eye blinking, retinal function, and pupil function even when using a lowlevel LED mask (Brouwer et al., 2017). Since the LED sheet, the material for this test, does not directly touch the eyes and does not use electric power, no additional stability tests on the subject were performed. As reported in other research papers on skin aging, eye wrinkles appear relatively quickly compared to other wrinkles, so early and continuous management is necessary (Kim \& Kang, 2012; Kim et al., 2019). Therefore, the objective of this experiment was to check whether eye wrinkles can be managed with an LED sheet mask. Even if the retina or skin is sensitive, an experiment was conducted to see if it is possible to care for wrinkles around the eyes without directly exposing the LED light. The skin wrinkle improvement effect of LED devices has been reported on the effect of light-emitting diode irradiation on skin condition improvement by Lee Jeong Hee (Lee et al., 2020).

Table 6 shows the evaluation results of eye expression wrinkles before use, immediately after use, and 24 hours after use after the product is used by the test subject. According to the evaluation results of light therapy LED sheet mask pack before and after eye expression wrinkles, $1.621 \%$ of wrinkles decreased by of the sheet pack immediately after use compared to before use. Significant results were confirmed in that $4.579 \%$ of eye expression wrinkles were reduced $(p<0.05)$ after use for 1 week (Table 6)

\section{4) Change in improvement of facial (cheek) lifting}

Although the aging process is slower on the cheeks than eye wrinkles, the cheeks and cheekbones are the most exposed to UV rays. Therefore, the cheek area is inevitably prone to aging or wrinkles. In a paper by Neil S Sadick, MD, it was proved that a lifting effect of $74 \%$ can be confirmed after 5 weeks when an LED mask using a low-level power in a wavelength band of 633nm is used for 9 weeks (Mordon et al. 2020). A facial (cheek) lifting test was performed to prove the lifting effect of the cheek part, which is attached to the largest area in the application area of the LED sheet mask used in this study.

After having the test subject use the product, before use, immediately after use, 24 hours after use facial (cheek) lifting personality changes are shown in Table 8. After using the Light Therapy LED sheet mask pack, the angle of the face (cheeks) was reduced to $2.065 \%$ compared to before, and it was confirmed that the angle was reduced by $3.762 \%$ after one week of use. A decrease in facial angle means that the skin is elastic, and the change in eye expression wrinkles after use of the test product was significantly decreased $(p<0.05)$ immediately after use and one week after use compared with before use, which proves that it is effective for (cheek) lifting (Table 7).

\section{Efficacy evaluation result 2}

1) Evaluation survey result efficacy

A significant function was derived from this test product, and an efficacy evaluation survey was conducted to improve the moisturizing effect for 24 hours after use, skin elasticity, eye expression wrinkles, and facial (cheek) lifting. The average and standard deviation and the percentage of the number of test subjects for the answers are as follows.

The 24-hour moisturizing lasting power was 3.043 points, indicating that the majority responded that the effect was good, and the skin elasticity satisfaction was also 3.043 points, showing the same preference result. However, the majority said that the effect of improving the wrinkles on the eyes was good, but the average value was average, and the improvement of

Table 7. Facial (cheek) lifting evaluation results

\begin{tabular}{llcc}
\hline Classification & & R2 & Improvement rate (\%) \\
Before use & & $29.055 \pm 4.038^{1)}$ & $2.065 \%$ \\
Immediately after use & & $28.455 \pm 4.032$ & $3.762 \%$ \\
One week after use & Effect within the entity qualification & $27.962 \pm 4.072$ & $0.000^{* *}$ \\
$\begin{array}{l}\text { Within significance comparison } \\
\text { probability }\end{array}$ & Before use - Immediately after use & $0.000^{* *}$ & $0.000^{* *}$ \\
& Before use - one week after use & & \\
\hline
\end{tabular}

${ }^{* *} p<0.05$ by repeated-measures ANOVA, post hoc Bonferroni correction. Improvement rate $(\%)=(($ After-Before $) /$ Before $) \times 100$

${ }^{1)}$ Mean \pm standard deviation. 
facial (cheek) lifting also resulted in the same evaluation.

Regarding the improvement of skin elasticity, $100.000 \%$ of the test subjects, 24 hours of moisturizing, and $95.652 \%$ of the test subjects were evaluated as above average for the improvement of eye expression wrinkles and facial (cheek) lifting. Therefore, the Light Therapy LED mask pack came out 'average' rather than 'very good' in terms of functional wrinkle improvement or lifting for the general public. As the need for anti-aging grows, there are cases where LED masks are used after applying functional cosmetics. As there are cases where a hyaluronic acid ampoule that is (Kim et al., 2020) effective for moisture supply and elasticity was applied and an LED mask was applied], products supplemented with an essence or specific ingredients for a more dramatic effect are required to be improved (Table 8).

\section{2) Survey results of product preference}

After use of the product, the test subject's preference for skin moisture, smoothness, adhesion, absorbency, fragrance, and overall feeling of use was investigated. The average and standard deviation, and the percentage of the number of test subjects for the answer, led to the following survey results.

The use satisfaction for skin moisture was good at 3.130 points, smoothness at 3.043 points, good adhesion at 3.174 points, absorption at 3.304 points as good, and fragrance as good at 3.000 points. As a result of the questionnaire evaluation, which received a good score of 3 points overall, it was evaluated as a good score of 3 points for absorbency, fragrance, and overall feeling of use. In $100.00 \%$ of test subjects, $95.651 \%$ of skin moistness and smoothness, and $95.653 \%$ of adhesion were evaluated as 'above average' (Table 9).

Table 8. Product efficacy evaluation survey results

\begin{tabular}{|c|c|c|c|c|c|c|c|c|}
\hline & & $4^{*}$ & $3^{*}$ & $2^{*}$ & $1^{*}$ & $0^{*}$ & Average & $\begin{array}{l}\text { Standard } \\
\text { deviation }\end{array}$ \\
\hline \multirow{2}{*}{24 hour moisturizing lasting } & $\mathrm{N}$ & 7 & 11 & 4 & 1 & 0 & \multirow{2}{*}{3.043} & \multirow{2}{*}{0.825} \\
\hline & $\%$ & 30.435 & 47.826 & 17.391 & 4.348 & 0.000 & & \\
\hline \multirow{2}{*}{ Skin elasticity improvement } & $\mathrm{N}$ & 6 & 12 & 5 & 0 & 0 & \multirow{2}{*}{3.043} & \multirow{2}{*}{0.506} \\
\hline & $\%$ & 26.087 & 52.174 & 21.739 & 0.000 & 0.000 & & \\
\hline \multirow{2}{*}{$\begin{array}{l}\text { Eye expression wrinkles } \\
\text { improvement }\end{array}$} & $\mathrm{N}$ & 4 & 14 & 4 & 1 & 0 & \multirow{2}{*}{2.913} & \multirow{2}{*}{0.733} \\
\hline & $\%$ & 17.391 & 60.870 & 17.391 & 4.348 & 0.000 & & \\
\hline \multirow{2}{*}{ Facial (cheek) lifting improvement } & $\mathrm{N}$ & 5 & 13 & 4 & 1 & 0 & \multirow{2}{*}{2.957} & \multirow{2}{*}{0.767} \\
\hline & $\%$ & 21.739 & 56.522 & 17.391 & 4.348 & 0.000 & & \\
\hline \multicolumn{9}{|c|}{ "4: Very good, 3: Good, 2: Average, 1: Bad, 0: Very bad } \\
\hline
\end{tabular}

Table 9. Product efficacy evaluation survey results

\begin{tabular}{|c|c|c|c|c|c|c|c|c|}
\hline & & $4^{*}$ & $3^{*}$ & $2^{*}$ & $1^{*}$ & $0^{*}$ & Average & $\begin{array}{l}\text { Standard } \\
\text { deviation }\end{array}$ \\
\hline \multirow{2}{*}{ Skin moisture } & $\mathrm{N}$ & 9 & 9 & 4 & 1 & 0 & \multirow{2}{*}{3.130} & \multirow{2}{*}{0.869} \\
\hline & $\%$ & 39.130 & 39.130 & 17.391 & 4.348 & 0.000 & & \\
\hline \multirow{2}{*}{ Skin smoothness } & $N$ & 7 & 11 & 4 & 1 & 0 & \multirow{2}{*}{3.043} & \multirow{2}{*}{0.825} \\
\hline & $\%$ & 30.435 & 47.826 & 17.391 & 4.348 & 0.000 & & \\
\hline \multirow{2}{*}{ Adhesiveness } & $\mathrm{N}$ & 8 & 12 & 2 & 1 & 0 & \multirow{2}{*}{3.174} & \multirow{2}{*}{0.778} \\
\hline & $\%$ & 34.783 & 52.174 & 8.696 & 4.348 & 0.000 & & \\
\hline \multirow{2}{*}{ Absorbency } & $\mathrm{N}$ & 8 & 14 & 1 & 0 & 0 & \multirow{2}{*}{3.304} & \multirow{2}{*}{0.559} \\
\hline & $\%$ & 34.783 & 60.870 & 4.348 & 0.000 & 0.000 & & \\
\hline \multirow{2}{*}{ Scent } & $\mathrm{N}$ & 4 & 15 & 4 & 0 & 0 & \multirow{2}{*}{3.000} & \multirow{2}{*}{0.603} \\
\hline & $\%$ & 17.391 & 62.217 & 17.391 & 0.000 & 0.000 & & \\
\hline \multirow{2}{*}{ Overall sense of use } & $\mathrm{N}$ & 6 & 11 & 6 & 0 & 0 & \multirow{2}{*}{3.000} & \multirow{2}{*}{0.739} \\
\hline & $\%$ & 20.087 & 47.826 & 26.087 & 0.000 & 0.000 & & \\
\hline \multicolumn{9}{|c|}{ *4: Very good, 3: Good, 2: Average, 1: Bad, 0: Very bad } \\
\hline
\end{tabular}




\section{Conclusions}

In this test, women aged 30-55 years were asked to use the Light Therapy LED mask sheet once or for a week, and 24-hour moisturizing durability, skin elasticity, eye expression wrinkles, and facial (cheek) lifting effects were proved as objective indicators. The use of cosmetics with active ingredients that can affect the test results of the Light Therapy LED sheet mask, a test product that can be used without power, was prohibited. It was found to be effective in improving skin elasticity and improving eye ex-pression wrinkles and facial (cheek) lifting after one week of use, helping to maintain moisture for 24 hours with one use. Through these results, it was possible to objectively evaluate the value of the utility applied to the skin with the Light Therapy LED sheet mask pack with the same principle as the expensive LED device.

\section{Author's contribution}

HK did research design, performed experiments, data collection and analysis, and wrote overall papers, and HK did advisory. All authors read and approved the final manuscript.

\section{Author details}

Hyejeong Koo (Graduate student), Division of Beauty Arts Care, Department of Practical Arts, Graduate School of Culture and Arts, Dongguk University, 30, Pildongro 1-gil, Jung-gu, Seoul 04620, Korea; Ki Han Kwon (Professor), Division of Beauty Arts Care, Department of Practical Arts, Graduate School of Culture and Arts, Dongguk University, 30, Pildong-ro 1-gil, Jung-gu, Seoul 04620, Korea.

\section{References}

Arci P, Gupta GK, Clark J, Wikonkal N, Hamblin MR. Low-level laser (light) therapy (LLLT) for treatment of hair loss. Lasers in Surgery and Medicine, 46: 144-151, 2014.

Brouwer A, Nguyen HT, Snoek FJ, Raalte DH, Beekman ATF, Moll AC, Bremmer MA. Light therapy: is it safe for the eyes? Acta psychiatrica Scandinavica, 136: 534-548, 2017.

Choi SJ, Baeck SW, Choi MH, Jo A, Jang HH, Oh CR, Ahn KJ, An
IS, An S, Oh JS. Effects of the face pack containing kaolin, adenosine and plant extracts on the skin improvement. Asian Journal of Beauty and Cosmetology, 11: 993-1000, 2013.

Gupta A, Arci P, Sadasivam M, Chandran R, Parizotto N, Vecchio D, de Melo W, Dai T, Chiang LY, Hamblin MR. Shining light on nanotechnology to help repair and regeneration. Biotechnology Advances, 31: 607-631, 2013.

Kim CH, Cheon MW, Park YP. Development and characterization of the optical power of LED mask for acne treatment. Journal of Digital Contents Society, 21: 245$250,2020$.

Kim JY, Jeon MJ. An exploratory study on the actual conditions of use of sheet mask packs, purchase behavior and satisfaction. Journal of Beauty Industry, 14:53-69, 2020.

Kim MS, Kang SM. The effect analysis on middle-aged women's facial wrinkles improvement of shaking neck exercise and collagen Diet. Journal of the Korean Society of Cosmetology, 18: 597-608, 2021.

Kim JT, Bae SB, Youn DY. Medical treatment machinery based on LED light source. Electronic and Telecommunications Trends, 25: 59-71, 2010.

Kim KB, Kim JY, An S, Min E, Bae S. Evaluation of the perception and clinical characteristics of facial skin aging according to age-group among Korean women. Asian Journal of Beauty and Cosmetology, 17: 387-396, 2019.

Kim DS, Song KU, Lee HK, Park JH, Kim BJ, Yoo KH, Shin $\mathrm{JH}$. Synergistic effects of using novel home-use 660and 850-nm light-emitting diode mask in combination with hyaluronic acid ampoule on photoaged Asian skin: a prospective, controlled study. Journal of Cosmetic Dermatology, 19: 2606-2615, 2020.

Ko KR, Effect of irradiation with visible light (green, red, blue) on inhibition of melanin biosynthesis. Asian Journal of Beauty and Cosmetology, 19: 13-21 2020;

Lee JH, Ha SY, Moon JS. Study on the effect of light emitting diode irradiation on improving skin condition. Journal of the Korean Applied Science and Technology, 37: 17981805, 2020.

Lee YK, Kim JD. Influence of sun-expose on the skin aging. Journal of the Korean Society of Cosmetology, 13: 841850, 2007.

Mordon S, Vignion-Dewalle, Abi-Rached H, Thecua E, Lecomte 
F, Vicentini C, Deleporte P, Behal H, Kerob D, Hommel T, Duhamel A, Szeimies RM, Mortier L. Testing a new light therapy for the treatment of actinic keratosis. British Journal of Dermatology, 182: 76-84, 2020.

Ng JNC, Wanitphakdeedecha R, Yan C. Efficacy of home-use light-emitting diode device at 637 and 854-nm for facial rejuvenation: a split-face pilot study. Journal of Cosmetic Dermatology, 19: 2288-2294, 2020.

Roelandts R. A new light on Niels Finsen, a century after his noble prize. Photodermatology, Photoimmunology \& Photomedicine, 21: 115-117, 2005.

Shen J, Lu XG, Jin JJ, Wang HW. Combination of a 2940 nm Er:
YAG laser with recombinant bovine basic fibroblast growth factor (rb-bFGF) and light-emitting diode-red light (LED-RL) for the treatment of striae alba: a pilot study. Journal of Cosmetic Dermatology, 17: 176-183, 2018.

Shim JH. Anti-aging effect of sulfuretin in UVA-irradiated normal human. Asian Journal of Beauty and Cosmetology, 18: 265-272, 2020.

Wheeland RG, Dhawan S. Evaluation of self-treatment of mild-to-moderate facial acne with a blue light treatment system. Journal of Drugs in Dermatology, 10: 596-602, 2011. 


\section{국문초록}

\section{자가발광 LED 광원을 이용한 텐셀 시트 마스크 팩의 피부개선 효과}

구혜정, 권기한

동국대학교 문화예술대학원 실용예술학과 뷰티아트케어전공, 서울, 한국

목적: 본 연구는 기존의 광테라피 LED 마스크 디바이스에서 증명된 효능들이 전력이 필요 없는 자가발광 $\mathrm{LED}$ 시트 마스크에서도 유사하게 발휘하는지 증명하고자 한다. 방법: 본 연구는 시험 결과에 영향을 미칠 수 있는 활성 성분이 포함된 화장품 사용을 금하 고 LED 시트형 마스크 팩을 사용함으로써 평균연령 47.9 세의 여성을 대상으로 24 시간 보습 지속력 측정, 피부 탄력 측정, 눈가 표 정 주름 측정, 안면(볼) 리프팅 개선 효과를 연구 진행하였다. 결과: 실험 후 24 시간 보습 지속력은 사용 직후 $90.573 \%$, 사용 24 시간 후 $37.384 \%$ 로 유의하게 증가 $(p<0.05)$ 하였고, 피부탄력도 사용 직후 $7.087 \%$, 사용 1 주 후에는 $11.181 \%$ 로 유의하게 증가 $(p<0.025)$ 하였다. 눈가 표정 주름은 사용 직후 $1.621 \%$, 사용 1 주 후 $4.579 \%$ 로 유의하게 감소( $p<0.05)$ 하였고 안면(볼) 리프팅 실험에서는 볼 부위 각도( $\left(^{\circ}\right)$ 가 사용 전과 비교하여 사용 직후 $2.065 \%$, 사용 1 주 후에는 $3.762 \%$ 의 결과로 유의하게 감소 $(p<0.05)$ 하여 광테라피 $\mathrm{LED}$ 시트 마스크도 피부 개선에 효과적임을 증명하였다. 결론: 본 연구자료를 기초자료로서 활용하여 효과적인 광테라피를 활용한 간편하면서도 단순한 구조의 마스크팩 외 피부관리 제품이 다양하게 개발됨을 기대해 본다.

핵심어: 자가발광LED, 광테라피, $\mathrm{LED}$ 시트 마스크팩, 피부보습, 피부탄력

\section{참고문헌}

고경륜. 가시광선(녹색, 적색, 청색) 조사에 따른 멜라닌 생합성 억제 효과. 아시안뷰티화장품학술지, 19: 13-21 2020. 김기쁨, 김지예, 안성관, 민은설, 배승희. 한국 성인 여성의 연령별 얼굴 노화 정도에 대한 인식과 임상학적 특성에 관한 연 구. 아시안뷰티화장품학술지, 17: 387-396, 2019.

김민승, 강상모. 좌우 목운동 및 콜라겐 식이가 중년 여성의 얼굴 주름 개선에 미치는 영향 분석. 한국미용학회지, $18:$ 597-608, 2021.

김지윤, 전미정. 시트형 마스크팩 사용실태와 구매 행동과 만족도에 관한 탐색적 연구. 뷰티산업연구, 14: 53-69, 2020. 김진태, 배성범, 윤두현, 피부질환 치료용 LED 치료기. 전자통신동향분석, 25: 59-71, 2010.

김찬희, 천민우, 박용필, 여드름 치료 적용을 위한 LED 마스크의 개발 및 광출력 특성 분석. 디지털콘텐츠학회논문지, $21:$ $245-250,2020$

심중현. 자외선 조사에 의해 노화된 인간각질형성세포에서 sulfuretin의 항노화 효능. 아시안뷰티화장품학술지, 18: 265-

$272,2020$.

이윤경, 김주덕. 자외선 노출이 피부노화에 미치는 영향. 한국미용학회지, 13: 841-850, 2007.

이정희, 하성이, 문지선. Light Emitting Diode 조사가 피부상태 개선에 미치는 효과 연구. 한국응용과학기술학회지, 37 : 1798-1805, 2020.

최성진, 백승우, 최민화, 조아령, 장현희, 오창록, 안규중, 안인숙, 안성관, 오정숙. 카올린, 아데노신 및 식물복합추출물이

함유된 안면팩의 피부개선 효과. 아시안뷰티화장품학술지, 11: 993-1000, 2013. 


\title{
中文摘要
}

\section{使用自发光LED光源的天丝片面膜的皮肤改善作用}

\author{
具惠貞，權起漢 \\ 东国大学文化艺术大学院实用艺术学科美容艺术护理专业，首尔，韩国
}

目的: 本研究旨在证明在现有光疗LED面罩装置中已经证明的功效是否同样适用于不需要电源的自发光LED片状 面罩。方法: 本研究的实验对象为平均年龄47.9岁的女性, 通过禁止使用可能会影响结果的含有活性成分的化妆 品, 研究LED 片式面膜对改善24小时保湿效果、皮肤弹性、眼部波纹、面部（脸颊）提升的效果。结果：实验 结果显示，使用后即刻24小时保湿力为 $90.573 \%$ ，使用 24 小时后为 $37.384 \%$ ，显着提升 $(p<0.05)$ ，使用后肌 肤弹性也提升 $7.087 \%$ 。用。一周后, 显着增加 $(p<0.025)$ 至 $11.181 \%$ 。立即使用后眼周的表情皱纹显着减少 $(p<0.05)$ 至 $1.621 \%$ 和使用 1 周后的 $4.579 \%$ 。在面部（脸顿）提升实验中，与使用前相比，使用后立即将 脸颊角度 $\left(^{\circ}\right)$ 降低到 $2.065 \%$ 。此外, 使用1周后显着降低 $(p<0.05)$ ，结果为 $3.762 \%$, 证明光疗LED面膜对皮 肤改善也有效。结论: 以此研究资料为基础数据, 预计将开发出各种护肤产品以及结构简单、方便的有效光疗面 膜。

关键词: 自发光 LED, 光疗, LED 面膜面膜, 皮肤保湿, 皮肤弹性 